\title{
Transendentale kritiek en negatiewe dialektiek: 'n vergelyking tussen Dooyeweerd en Adorno se samelewingskritiek
}

\author{
Johan Snyman \\ Departement Filosofie \\ Randse Afrikaanse Universiteit \\ JOHANNESBURG
}

\begin{abstract}
Transcendental critique and negative dialectics: a comparison between Dooyeweerd's and Adorno's social critique

Plato's allegory of the cave set a fashion for philosophy, i.e. to distinguish between appearance and reality. This fashion is still distinguishable in the work of two philosophers whose social critiques, at a first glance, are worlds apart: Herman Dooyeweerd of the Free University in Amsterdam, and Theodor Adorno of the Johann Wolfgang Goethe University in Frankfurt. Upon a closer look, however, many similarities appear. Their diagnoses of Western society probes beneath the beguiling surface of scientific and technological progress to reveal serious tensions deeply embedded in Western culture. The question arises: how conscious are they of their own embeddedness in this cultural crisis? Dooyeweerd and Adorno are analysed on this issue, and the conclusion shows Dooyeweerd's philosophy to suffer from an intellectual hybris, whereas Adorno's is portrayed as burdened with a paralysing aestheticism. The result of this critical analysis of Dooyeweerd and Adorno is a suggestion to rehabilitate the tradition of Christian thinking as an ongoing debate between rival interpretations of the biblical message, which offers creative opportunities to respond to cultural crises and the suffering they entail.
\end{abstract}

\section{Inleiding}

Onder al die baie dinge wat oor filosofie gesê word, is daar een wat besonderlik van toepassing is op hierdie onderwerp. Dit is naamlik die gedagte dat filosofie die mens(dom) in staat stel om tussen sitroene en 
Transendentale kritiek en negatiewe dialektiek

knolle te onderskei, en veral om knolle raak te sien waar baie dink daar is sitroene. Filosofie is die pretbederwer: dit ontmasker die werklikheid as skyn, en soek die werklikheid elders. Soos Marthinus Versfeld sê: die filosoof "spoeg ... teen die wind van die bewind, soms met 'n baie floue hoop dat hy gehoor sal word. ... Die poging van die filosoof wat sy kop uitsteek, is om die seile van die bewind met daardie heilsame wind ['n bries wat uit die hemelpoorte waai] te vul sodat die mensdom deur die storms weer hawe en tuiste sal bereik. Hoe om deur hierdie see koers te hou sonder om onder die branders van die wanhoop te versuip, is sy innerlikste probleem. Sonder hoop kan daar geen filosofie bestaan nie, en daardie hoop berus op geloof wat 'n onsigbare wêreld met oorgawe aanvaar" (Versfeld, 1986:3).

Die aartsvader van die filosoof as die skyn(ver)werper is natuurlik Plato. Volgens sy oorbekende grot-allegorie ontstem die filosoof diegene wat hulle met hulle lot in die halfdonker grot versoen het, deur aan hulle te vertel dat daar oneindig meer aan die wêreld is as wat hulle dink. Die filosoof maak nie net hulle wêreldervaring verdag nie, hy wil ook hê dat hulle self agterdogtig moet raak oor hoe die wêreld hom aan hulle voordoen. Dit is nie heeltemal duidelik waarom die grotbewoners ontstem is nie. Is hulle vir die filosoof kwaad omdat hy hulle rus verstoor, of omdat hy hom dinge oor hulle aanmatig? Wat ook al die geval is, die hermeneutiek van suspisie het 'n prys. Plato vertel dat diegene wat met hulle lot in die grot versoen is, die renegaat van die lig wil doodmaak oor sy boodskap.

Dit is en bly ' $n$ baie interessante verhaal oor die rol van filosofie - 'n gelykenis waarvan die bekoring nog glad nie verdof het nie. Daar is verskeie redes waarom hierdie gelykenis oor die rol van filosofie bekoor. Vir sommige is daar die verleiding van mag: die filosoof is die dissident wat oor die vermoë beskik om die houvas van die gewone en alledaagse te verbreek en deur te tas tot iets diepers en meer verborge. Die filosoof weet iets wat ander nie weet nie, en hy/sy kan ander in staat stel om hierdie verborgene te bekom en bevry te wees van die beperkings van onkunde. Daar is egter diegene wat die verleiding van die mag van Koning Eenoog kan weerstaan. Dié begenadigdes word gelok deur die belofte van bevryding deur waarheid: om die sluier van die buierige onmiddellike af te skud en daaragter die essensie te kan peil is om 'n ondubbelsinnige sin vir die verganklike te vind en 'n roetekaart te hê na die onveranderlike en blywende toe. Sodra die motief vir die navolging van hierdie regverdiging 
Johan Snyman

van filosofie duidelik blyk, wat dit dan ook al mag wees, kom nuwe uitdagende vrae in sig. Die spanning tussen die gewone en die dieperliggende, tussen skyn en werklikheid, tussen die vanselfsprekende en die onvanselfsprekende, word iets wat om antwoorde roep. Filosofie word 'n speurtog - na 'n verlore of 'n vergete werklikheid, en na die redes vir die vergetelheid of verlorenheid. En met rukke raak die speurder aan die wonder oor homself of haarself: hoe het hy/sy dan op hierdie spoor gekom?

Dit is die fassinerende van Plato se oergelykenis oor die filosofie: hoe het daardie eerste dissident op die gedagte gekom dat daar iets anders moes wees as net die blote opgeefsels teen die muur van die grot? Daar is wel die moontlikheid van 'n verklaring by Plato self: die dissident herinner hom vaagweg iets beters uit 'n vorige lewe, en geleidelik groei hierdie herinnering tot die daad van die Groot Weiering. Maar sê nou 'n mens is nie Plato se metafisiese wêreldbeeld toegedaan nie, moet 'n mens aanvaar die dissident word gevoed vanuit een of ander verborge kollektiewe herinnering soos die tradisie? Maar watter gesag het die tradisie in ons era van die kollektiewe geheueverlies en kitsverbruik? Waar kom die kritiese distansie ten opsigte van die werklikheid vandaan by mense wat in daardie werklikheid gebore en getoë is? Hoe is kritiek moontlik, en hoe word dit begrond? Is een of ander religieuse motief of een of ander sosiale beheersingsmotief die diepste dryfveer van ons wêreldontwerpe?

Om hierdie vraag te verken, gaan ek na twee eietydse vorme van die Platoniese oergelykenis van die filosofie kyk. Op die eerste aansig het hulle weinig meer as hulle ontstaanstyd gemeen. Ek praat van die Wysbegeerte van die Wetsidee van Herman Dooyeweerd en van die Negatiewe Dialektiek van Theodor Wiesengrund Adorno. Ek gebruik hierdie name en titels as verteenwoordigend (en dus onvermydelik en ten onregte veralgemenend) van twee onderskeie stromings in die twintigste-eeuse filosofie vir die gerief van 'n vergelyking, en vir 'n toegespitste nadenke oor die rol van filosofie onder gegewe omstandighede.

Wat het die Reformatoriese wysbegeerte van Amsterdam en die NeoMarxistiese samelewingskritiek van die sogenaamde Frankfurtse Skool gemeen? Met 'n tweede kyk beslis meer as die feit dat elkeen sy beslag in die dertigerjare van hierdie eeu gekry het. Dooyeweerd se Wijsbegeerte der Wetsidee verskyn as 'n soort programgeskrif in 1935, terwyl Max Horkheimer se Traditionelle und kritische Theorie, eweneens 'n programgeskrif, in 1937 die lig sien. In albei hierdie werke word die vooruitgangsgeloof van die Verligting van die agtiende eeu krities in 
oënskou geneem as die resultaat van 'n rasionaliteit wat hopeloos ontspoor het en daarom op 'n nuwe grondslag, buite die eng grense van rasionaliteit soos dit tot op daardie stadium gedefinieer is, geplaas moet word. Saam met enkele ander laat die Amsterdamse Calviniste en die Frankfurtse NeoMarxiste stemme opgaan oor die krisis van die sogenaamde projek van die moderne. Albei rigtings trek te velde teen die sogenaamde outonomie van die rede en die wetenskap, en albei is sterk geïnteresseer in 'n "maatschappij der toekomst" (vergelyk Van Riessen, 1957) waarin tegnologiese rasionaliteit ' $n$ ander, en liefs menslike, rol moet speel. By sowel Dooyeweerd as Adorno is daar 'n verset teen die nivellerende identiteitsdenke van moderniteit, met as alternatief ' $n$ doelbewuste poging om die sogenaamde nie-identiese te red. (Dooyeweerd is in hierdie opsig meer kosmologies georiënteer - dit gaan vir hom om die onherleibaarheid van 'n kosmiese verskeidenheid, terwyl Adorno 'n sosiale fokus het in die sorg om die onhoorbaar geworde individu.) Al twee rigtings organiseer hulleself bewus en opsetlik: rondom die reformatoriese filosofie ontstaan 'n Vereniging voor Calvinistische Wijsbegeerte met verskeie tydskrifte, en hierdie vereniging slaag daarin om 'bezondere leerstoelen' in Calvinistiese Filosofie aan verskeie Nederlandse universiteite ingestel te kry. In Frankfurt word die Institut für Sozialforschung opgerig, met 'n goed beplande en vir sy tyd baanbrekende program vir interdissiplinêre navorsing onder leiding van Max Horkheimer, en ook 'n mondstuk in die vorm van 'n wetenskaplike tydskrif. Albei rigtings desintegreer in 'n sekere sin onder die aanslag van die studentebeweging van die laat sestigerjare. Die Vrije Universiteit se Centrale Interfaculteit (waar filosofie gehuisves is) het in die sewentigerjare 'links' geword (na Van Riessen se aftrede kon sy pos nie deur iemand uit die kring van die Reformatoriese filosofie gevul word nie). En Frankfurt het 'regs' geword: vir 'n geruime tyd na 1968 was daar min sprake van egte Kritiese Teorie in Frankfurt, totdat Habermas in 1984 na Frankfurt teruggekeer het en die Kritiese Teorie deur 'n 'wending tot die taal' gerehabiliteer het tot 'n Theorie des kommunikativen Handelns (Habermas, 1981).

Dit is met 'n derde opsetlike kyk dat die Platoniese oer-gelykenis in Amsterdam en in Frankfurt na die oppervlak kom. Duidelikheidshalwe stel ek 'n woordvoerder van elk aan die orde: 


\section{Eerstens Dooyeweerd:}

Philosophy is theoretical, and in its constitution it remains bound to the relativity of all human thought. As such, philosophy itself needs an absolute point of departure. It derives this exclusively from religion. Religion grants stability and anchorage even to theoretical thought. Those who think they find an absolute starting point in theoretical thought itself come to this belief through an essentially religious drive, but because of a lack of true self-knowledge they remain oblivious to their own religious motivation.

Let no one, therefore, try to correct the religious dialectic by way of the theoretical dialectic ... That approach is an utterly uncritical form of dialectical thought, because at the root of its overestimation of the theoretical dialectic lies a religious dialectic that is hidden to the thinker himself.

What is at stake in the issue of the antithesis is the relation between religion and temporal life. This is not a purely theoretical matter of interest only to theoreticians. Since the antithesis touches the deepest level of our existence as human beings, it is a problem that concerns everyone. Whoever delegates it to theory shirks his personal responsibility. One cannot escape from oneself behind an impersonal science, for the only answers science gives to the central questions of life are religiously biased.

It is essential for the welfare of contemporary culture that the religious roots of its various streams be uncovered and explored (Dooyeweerd, 1979[1959]:8, 13, 14-5; vergelyk ook Dooyeweerd, 1953:61-68).

\section{Vervolgens dan Adorno: ${ }^{1}$}

Soos wat filosofie die misleiding van die verskynsels wantrou en [daarom] bedag is op duiding, soveel te meer wantrou [sosiale] teorie die fasade van die samelewing hoe gladder hierdie fasade telkens voorkom. Teorie wil [uiteindelik] 'n naam gee aan dit wat die meganisme in die geheim bymekaarhou. ... Dit wil die klip oplig waaronder die onding uitbroei. In die kennis van die onding alleen bestaan die sin van teorie (Adomo, 1972b:196).

Dialektiek is die selfbewussyn van die objektiewe verblindingsamehang ... Om uit hierdie samehang, van binne uit, te breek, is die objektiewe doel van die dialektiek. Die krag tot hierdie uitbreek groei vanuit die immanensiesamehang na die dialektiek toe. 'n Mens sou Hegel se uitspraak hierop van toepassing kon maak, naamlik dat die dialektiek die krag van sy teenstaander in homself absorbeer en teen die teenstaander aanwend ... [Dialektiek] vat met die middele van die logika die dwingende karakter daarvan in die hoop

I Afrikaanse vertalings van Duitse bronne (Adomo, Krahl, Marquard, Smith) is my eie - JS. 
dat dit sal wyk. Want elke [vorm van] dwang is self mitiese skyn, die gedwonge identiteit. Aan die ander kant is die absolute, soos die metafisika dit graag voorhou, die nie-identiese wat eers te voorskyn tree nadat die dwang tot identiteit vergaan het. Sonder die identiteitstese is dialektiek ook nie die geheel nie. Dan is dit egter ook geen kardinale sonde om die dialektiek in 'n dialektiese stap te verlaat nie. Dit lê in die bepaling van die negatiewe dialektiek dat dit nie vrede daarmee het asof die negatiewe dialektiek self totaal is nie, en dit is sy vorm van hoop (Adorno, 1967:396).

Hier is twee diskoerse aan die orde gestel - elkeen het sy eie woordeskat, sy eie onderskeidings, sy eie ordes. Wat egter onmiskenbaar by elkeen aanwesig is, is die gedagte van onthulling. Elkeen wil die skyn ontmasker. Dooyeweerd wil by die diep verborge religieuse wortels van die kultuurkrisis uitkom en Adorno praat van 'n "meganisme" wat "agter 'n fasade" die samelewing "in die geheim" "bymekaarhou". Die verborgenhede van die alledaagse werklikheid is inderdaad te diep vir Jan Publiek om te peil. Maar die skyn is nie 'n blote opgeefsel nie. 'n Mens bly nie onaangeraak daardeur nie - dit is 'n skadelike werklikheid; skadelik daarin dat dit voorgee om iets te wees wat dit in werklikheid nie is nie. Die tragiek is dat mense onbewuste slagoffers is van hierdie bedrieglike werklikheid, en daarom het hulle filosofie nodig om hulle van die instrumentarium te voorsien om hierdie werklikheid na sy skyn te kan ontsyfer en te kan voorsorg tref vir 'n beter toekoms.

Maar is hierdie ooreenkoms tussen 'n Dooyeweerd en 'n Adorno nie self skyn nie? Waarom is die diskoerse so uiteenlopend, selfs op die eerste aanhoor? En vir diegene wat meer vertroud is met die geskrifte van Dooyeweerd en Adorno word die skyn des te bedriegliker, omdat in die aangehaalde gedeeltes Dooyeweerd appelleer op iets wat transendent aan denke is, terwyl Adorno hom juis beroep op dit wat Dooyeweerd sonder ophou kragtig afwys, naamlik vertroue op immanensie.

Ons het hier met 'n moeilike hermeneutiese kwessie te make. Verstaan Dooyeweerd en Adorno dieselfde onder 'die absolute' en 'immanensie'? Is hulle uiteindelik vergelykbaar? Ek wil uiteindelik 'n saak daarvoor uitmaak dat hulle dieselfde siening van filosofie toegedaan is, en dat daar vergelykbare oorsake vir hulle onderskeie programme is. Om uit te maak waarom hulle elkeen 'n hermeneutiek van suspisie bedryf, en hoe hulle daarop gekom het, volg ek die omweg om in meer besonderhede op die motivering van elkeen se taakomlyning van filosofie in te gaan. 
Johan Snyman

\section{Dooyeweerd as skyn(ver)werper}

Dooyeweerd se Wijsbegeerte der Wetsidee het in die Engelse vertaling die veelseggende titel: A New Critique of Theoretical Thought, met 'n uitgebreide inleiding wat in die oorspronklike ontbreek. Dooyeweerd wil aantoon dat die teoretiese rede, wat die mens in staat stel om die wêreld te ken, te verklaar en te beheers, sy taak nie behoorlik kan uitvoer as dit nie bewus is van sy verworteling in die religie nie - en meer spesifiek in die egte Christelike religie nie. Die transendentale kritiek wat Dooyeweerd op die spoor van Kant hiervoor ontwerp, wil ingaan op die noodsaaklike en voldoende voorwaardes eie aan enige vorm van teoretiese denke. Uit hierdie voorwaardes van denke self moet die denke se behoefte aan ' $n$ religieuse verankering blyk, en daarmee die onmoontlikheid van die denke se selfgenoegsaamheid ten opsigte van wat tot dusver in die tradisie van Westerse rasionaliteit as buite- en onredelik gediskwalifiseer is.

Om aan hierdie onderneming uitvoering te gee, hou Dooyeweerd hom aan die parameters van die Neo-Kantianisme wat die hoofsaak van filosofie benader as die begronding van kennis. Daarmee word die filosofiese horison, soos deur Kant geskets in sy uitwerking van die projek van die moderne (vergelyk Habermas, 1985:30-33), ingeperk to die horison van die teoretiese rede alleen. Dooyeweerd, soos talle Kantiane en NeoKantiane, verreken nie die volle omvang van Kant se kritiese projek nie, maar fikseer moderniteit op die eerste kritiek van Kant.

Dooyeweerd interpreteer die werk van die rede na aanleiding van die alchemistiese metafoor van die vervaardiging van kennis deur die verbinding van logiese elemente met ander nie-logiese elemente. Vandaar dat 'n mens dan bio-logie, psigo-logie, en dies meer kry. Die probleem is dan dat 'n mens nie vanuit die perspektief van die logiese alleen kan bepaal of 'n goeie verbinding met die nie-logiese aangegaan is nie. 'n Mens het 'n waarnemingspunt nodig wat 'n uitsig op sowel die logiese as die nielogiese kan bied om te verseker dat daar nie 'n onverantwoordbare eensydigheid in die verbinding is nie. Daarvoor is ' $n$ Archimedespunt nodig. Hierdie verdere metafoor wat Dooyeweerd inspan, is nie net gekies om iets te suggereer van uitsig en oorsigtelikheid nie, maar suggereer ook iets van 'n punt waarvandaan met hefboomkragte ingegryp kan word om balanse te herstel. Die punt wat Dooyeweerd met hierdie metaforiek maak, is dat die logiese instrumentarium alleen nie kan beslis oor die sinvolheid al dan nie van ons kennismaking met die wêreld nie. Die sintese van die logiese aspek met 'n nie-logiese aspek is nie die resultaat van die suiwer 
immanente aard van die logiese aspek nie. Die sintese is moontlik omdat daar 'n omvattender, dieper eenheid is wat dit bemoontlik - die eenheid gaan aan die sintese vooraf. En hierdie eenheid is gegee in die (metafisiese) oorsprong van die verskeidenheid van aspekte, naamlik God as Skepper. En die bewussyn hiervan kom slegs op in 'n gereflekteerde uitsig wat bo die verskillende elemente van enige moontlike sintese uitgaan - die Archimedespunt, 'n punt waarin teoretiese denke en ervaring getransendeer word en waar 'n ruimte geskep word vir die ontvouing van ' $n$ kennis van wat agter die bloot en streng logies afleibare lê. In navolging van Kant noem Dooyeweerd hierdie metafisiese kennis die transendentale grondidee - dit is nie ver van Kant se regulatiewe idee van God, siel en wêreld verwyder nie. Dit lei (in sowel Kant as in Dooyeweerd se geval) ons kennismakingsproses deur rigting daaraan te gee. Kant wil egter nie hê dat ons absolute sekerheid daaroor kan kry nie: empiries kan die idee van God nie geverifieer word nie, en intellektueel het dit nie sin om die idee te weerlê nie. Daarom maak ons ons kennis asof dit van 'n sinvol geskape samehang is. Dit is in ieder geval die enigste manier waarop ons sinvolle kennis kan kry. Dooyeweerd deel nie Kant se gereserveerdheid oor die sekerhede van die metafisika nie. By hom is sekerheid oor die transendente - as 'n persoonlike verhouding met die Skepper en Verlosser - 'n eksistensiaal wat in die aandrif tot die kennismaking met die wêreld gegee is, en wat daarom nie strategies later (hoewel onvermydelik by Kant, selfs as werkshipotese) in die denkproses aan die orde kom as regverdiging van die sinvolheid daarvan nie, maar as die alomvattende begronding van die denkproses reg van sy begin af.

Waarom is die hoofprobleem van filosofie vir Dooyeweerd die ontmaskering van die outonomie van teoretiese denke as skyn (teoretiese denke is naamlik nie outonoom nie, maar in die eerste en die laaste instansie afhanklik van religie)? 'n Voor die hand liggende antwoord (voor die hand liggend vir die Kantiaanse en Neo-Kantiaanse tradisie) lui: enige filosofie behoort krities aan sy eie aansprake getoets te word. As die Neo-Kantiane, met hulle indrukwekkende sistematiese en dwingend rasionele selfrefleksie oor die moontlikhede van die teoretiese rede meen om 'n afdoende begronding van die rede te gegee het, is dit niks meer as filosofiese regverdigheid dat hierdie aansprake ontmasker word as skyn nie. Dit is in belang van filosofie, en in die belang van die maak van kennis, dat onhoudbare opvattings voortdurend uitgesif word, en nuwe en plaasvervangende idees vir toetsing aangebied word. Dit is intellektuele integriteit om aangebode en gevestigde teorieë te beproef. En al word baie resultate 
Johan Snyman

uiteindelik omver gewerp, herskik dit ten minste die herinnering aan wat was en wat kon gewees het. Want dit wil lyk asof ons die kwaad slegs kan vermy as ons herinnering daarvan lewendig bly.

Maar so voor die hand liggend is die antwoord nie. 'n Verdere vraag kom na die oppervlakte: waarom word die ontmaskering van die outonomie van die rede as die hoofprobleem van die filosofie geïdentifiseer in die helfte van die twintigste eeu? Die vraag impliseer dat daar ander hoofopgawes mag wees, en dat Dooyeweerd se hoofopgawe nie 'n sitroen nie, maar 'n knol kan wees. Toegespits geformuleer: is religie werklik die laaste of diepste wortel van enige denke? Waarom is religie vir Dooyeweerd so belangrik, en nie vir die meeste ander denkers van die twintigste eeu wat ook oor die kultuurkrisis van die twintigste eeu nadink nie?

Die vraag impliseer dat dit moontlik is om transendentaal anders te reflekteer as Dooyeweerd, en op ander transendentale voorwaardes van teoretiese denke af te kom. As daar moontlik ander transendentale voorwaardes van teoretiese denke kan wees, waarom is dit vir Dooyeweerd so belangrik om die outonomie van denke as skyn te ontmasker? Watter saak maak dit vir Dooyeweerd, of behoort dit in die wêreld te maak dat die denke onselfgenoegsaam is? Die antwoord op hierdie vraag is te vind in 'n stuk ongereflekteerde sosiale geskiedenis waarin Dooyeweerd se filosofiese werk ingebed is.

Dooyeweerd was voordat hy die hoogleraarskap aan die Vrije Universiteit in Amsterdam aanvaar het, adjunk-direkteur van die Dr. Abraham KuyperStigting. Hierdie stigting is in die twintigerjare van hierdie eeu opgerig om die nodige wetenskaplike en teoretiese ondersteuning te gee aan die AntiRevolutionaire Staatspartij in Holland. Om dit baie kortliks saam te vat: vir die ARP en die Kuyperstichting was dit belangrik om die breeds moontlike intellektuele fundering te gee aan 'n bepaalde uitwerking van die liberale demokrasie wat gereformeerdgesindes in die samelewing die meeste burgerlike vryhede ten opsigte van hulle eie allesomvattende gereformeerde oortuigings aangaande kerk en lewe kon waarborg. Dit het hulle in die sogenaamde beginsel van soewereiniteit in eigen kring gevind, waardeur 'n historiese ervaring van die godsdiensoorloë tydens die Hervorming praktiese riglyn geword het, naamlik dat godsdiensverskille nie met die middele van die politiek besleg kan word nie omdat kerk en staat begrensde kompetensies het. Ter wille van die vryheid van die individu en die vrede van die gemenebes is dit wenslik om die soewereiniteit van elke institusie in die gemenebes te erken binne sy gesagskring 
wat eie aan hom is. In Holland is hierdie sogenaamde beginsel veral in die negentiende eeu gemobiliseer, eers deur Groen van Prinsterer, en toe deur Abraham Kuyper, om die opkoms van staatsabsolutisme effektief teen te werk - veral op die terrein van die nuut-ontwikkelende dienstesektor van die staat ten opsigte van gesondheids- en onderwysstrukture. Hierdie ontwikkeling skep nuwe probleme vir die onderwys. Onderwys is die proses waardeur die lede van 'n gemeenskap ingelei word in die sosiale prosesse wat noodsaaklik is vir die voortbestaan van daardie gemeenskap. Onderwys word nou 'n politieke aangeleentheid - die staat kry 'n belang by die gesosialiseerdheid van sy onderdane. Die probleem wat teengewerk is, is die vestiging van belange wat gepaard gaan met finansiering. As die staat onderwys finansier, eis hy seggenskap op in die bepaling van onderwysstandaarde en onderwysinhoude. Die doeltreffendheid van staatsonderwys verg maksimum resultaat met minimum insette. In die belang van staatsbesteding moet 'n gestandaardiseerde en neutrale onderrigprogram aangebied word. Die praktyk van 'n multikonfessionele samelewing wys egter gou uit dat die staat nie sonder meer die hoogste beliggaming is van die algemene belang van ' $n$ samelewing nie. Met ander woorde: die belange van die staat is nie noodwendig die belange van elke konstituerende gemeenskap in daardie staat nie. Daarom is die wysste strategie om deur onderhandelings reëls vir die onafhanklike funksionering van belangegemeenskappe te vestig, en dit is baie energiek gedoen deur geskrif en organisasie in die persone van Groen van Prinsterer en Abraham Kuyper. Van Prinsterer het die beginsel van soewereiniteit in eie kring as 'n regsbeginsel gevestig, en Kuyper het dit verder uitgebrei tot 'n beginsel veranker in die Skepping van 'n onherleibare verskeidenheid deur God. Die resultaat was uiteindelik die politiese, ideologiese en metafisiese verzuiling van die Nederlandse samelewing waarin die Kuyperstigting tot stand gekom het, en waarvan die jonge Dooyeweerd die adjunkdirekteur geword het. In sy "Nota" wat sy brief aan die sekretaris van die Kuyperstigting vergesel, en waarin Dooyeweerd sy aanvaarding van die aanstelling as adjunkdirekteur bevestig, skets hy die aard van die werksaamhede van die stigting onder sy toekomstige leiding:

Het Kuyperhuis zal naar mijn vaste overtuiging zijn taak eerst dan behoorlijk kunnen vervullen wanneer het adviezenbureau door systematischen wetenschappelijken arbeid wordt gevoed. Daartoe kan het niet voldoende zijn, dat voorkomende vragen ook wetenschappelijk worden bekeken. Een advies over een principieele strijdvraag, die tot het terrein der zgn. 'afgeleide vragen' behoort, veronderstelt, zal het rijp en van blijvende waarde zijn, een helder 
Johan Snyman

inzicht in de grondslagen der zgn. neo-calvinistische levens- en wereldbeskouing in haar toepassing op recht, economie en politiek.

Is de methode bepaald, dan zal het eerste werk zijn het grondprobleem van de geheele calvinistische rechts- en maatschappijbeschouwing, het souvereiniteitsprobleem aan een diepgaand onderzoek te onderwerpen. Vanuit de calvinistische souvereiniteitsleer moeten de lijnen worden getrokken voor de verhouding van kerk en staat, staat en maatschappij, overheid en onderdanen en de onderdanen onderling.

Mocht ik echter het adjunct-directeurschap kunnen aanvaarden dan zou ik na aanvankelijke terreinsverkenning en oriënteering naar alle zijden, zoo spoedig mogelijk de richting willen uitgaan, die ik hierboven heb aangegeven. En dan zal - want dat ligt in den aard der zaak - in de wetenschappelijke afdeeling, die het diepwater aan het adviezenbureau zal moeten toevoeren, ook het zwaartepunt van het Kuyperhuis moeten worden gelegd (Van Dijk e.a., 1961:49-51).

In die Calvinistiese lewens- en wêreldbeskouing word groot klem gelê op die feit dat die hele lewe van die mens 'n lewe voor die aangesig van God is. Charles Taylor verwys daarna as "... the affirmation that the fulness of Christian existence was to be found within the activities of this life, in one's calling and in marriage and the family" (Taylor, 1989:218). Die menslike rede kan homself nie van hierdie lewe voor die aangesig van God losmaak nie. As die menslike rede homself as grondslag van byvoorbeeld die moraal sou aandien, met die gedagte dat die mens slegs moreel optree in soverre hy/sy eiebelang kan bereken, in plaas daarvan dat die moraal uitgaan van die gedagte van ' $n$ roeping tot gehoorsaamheid aan die gebooie van God, is die sosiale resultaat allerlei vorme van onoplosbare sosiale spannings. En Dooyeweerd se agterdog teen die verselfstandigde rede word inderdaad gelyk gegee deur die Neo-Marxiste se kritiese ontmaskering van die instrumentele rede en in die jongste tyd deur Alasdair Macintyre se analise van die moraliteitskrisis (Macintyre, 1981). Dooyeweerd interpreteer die ontwikkeling van sosiale vraagstukke in Holland aan die einde van die negentiende eeu en die begin van die twintigste eeu, nie ten onregte nie, as die gevolge van die sekularisasieproses eie aan die moderniteitsprojek. Die kernprobleem van hierdie projek, waarin die mens nou die wêreld as sy/haar eie verantwoordelikheid ontdek (vgl. Blumenberg, 1974), is volgens Dooyeweerd die aanspraak op redelikheid as laaste fundering. Redelikheid is ten diepste nie selfgedrewe nie. Redelikheid is instrumenteel - daarvoor het Hobbes al die fondamente gelê. As oortuigde erfgenaam van die reformatoriese tradisie kan Dooyeweerd nie anders as om die rede ook as middellik te sien nie, maar

Koers 60(2) 1995:213-236 223 
Transendentale kritiek en negatiewe dialektiek

dan middellik in die lewe coram Deo. As die rede nie instrumenteel is in die ontvouing van die lewe in sy verskeidenheid roepings voor die aangesig van God nie, is dit instrumenteel in die vernietiging daarvan. Die rede is nie neutraal nie, maar religieus veranker. Of dit is in diens van God en die menslike lewe tot heil, of dit is in diens van anti-goddelike magte en daarom tot onheil van die mens. Dooyeweerd se strategie vir 'n beter samelewing is om by die wortel van die probleem te kom: die religieuse grondmotief van alle teoretiese aktiwiteit.

Met die opvatting oor die religieuse verworteling van die teoretiese denke staan en val Dooyeweerd se filosofie. Op hierdie punt is Dooyeweerd se filosofie besonder kwesbaar, veral as 'n mens die samevatting van die strekking van die Wysbegeerte van die Wetsidee deur Louet Feisser (1961:22-23) hierby in berekening bring:

\begin{abstract}
Dooyeweerd ... verklaart dat door de wijsbegeerte te beoefenen vanuit het op Christus als zijn oorsprong gerichte mensenhart, ons denken bevrijdt wordt van allerlei verabsoluteringen der verschillende ervarings- en werkelijkheidsaspecten, en zodoende tot een juist inzicht kan komen in de integrale samenhang van al deze aspecten. Anderzijds betoogt Dooyeweerd dat het, juist gezien het boven-theoretisch uitgangspunt van alle philosophie, nooit mogelijk kan zijn langs strikt-theoretische weg de tegenstander van zijn ongelijk te overtuigen.
\end{abstract}

Ek gaan nie in op die argumente wat Dooyeweerd aanvoer teen 'n inlees van 'n Skolastiese twee-terreineleer in sy opvatting oor die religieuse wortel van teoretiese denke nie. Wat vir die verdere betoog belangrik is, is dat Dooyeweerd die institusionele monopolisering van die Bybelse boodskap deur 'n kerklike belydenis onomwonde afwys, omdat die verhouding van die mens tot die Middelaar regstreeks is en nie verder bemiddel kan word sonder om die betekenis van die Middelaar in die gedrang te bring nie. Die sogenaamde Bybelse grondmotief van skepping, sondeval en verlossing wat die teoretiese denke rig, is dus - volgens die logika van Dooyeweerd se filosofie - voorteoreties, dit wil sê beslis nie die resultaat van 'n teologie nie, en geensins kerklik gesanksioneer nie. Dit is die regstreekse aanspreke van die Goddelike openbaring in die hart van die mens, en hierdie aanspraak resoneer op 'n besondere wyse met die diepste vraagstukke van die teoretiese denke wanneer dié oor sigself begin reflekteer. 
Johan Snyman

\section{Die oormoed van die Wysbegeerte van die Wetsidee}

Dit is bekend dat Dooyeweerd se filosofiese onderskeidings en sy ontwerp van 'n omvattende kyk op die wêreld die rol en posisie van die kerk problematiseer. Dit kan natuurlik nie anders nie - Dooyeweerd radikaliseer in hierdie opsig die nominalistiese erfenis van die Reformasie. Al wat vir Dooyeweerd werklik is, en waarop sy filosofiese nadenke gerig is, is die verhouding tussen die menslike individu (weliswaar as deel van die religieuse gemeenskap van die menslike geslag) en sy/haar Oorsprong, naamlik God. Eers op 'n tweede vlak word hierdie verhouding geïnstitusionaliseer in die kultiese gemeenskap van die kerk, maar dan as een wyse van institusionalisering naas ander (soos die skool, die staat en die bedryf). En die Christelikheid van die skool, staat en bedryf word nie deur die bestaan van die kerk in 'n samelewing gewaarborg nie, maar deur die werking van die grondmotief in die hart van die mens wat in die skool, staat en bedryf betrokke is. Dooyeweerd se opvatting oor die betekenis van religie maak die mens in 'n sekere sin mondig ten opsigte van die kerk as institusie. Dit is ' $n$ winspunt, maar nie sonder probleme nie.

Sy opvatting oor die religieuse grondmotiewe is op sigself problematies. Op die keper beskou, is grondmotiewe self konstruksies wat die resultaat is van nadenkende vergelykings van historiese ervaring. Individuele mense en gemeenskappe gee sin aan hulle historiese ervarings deur begrippe daarvoor te skep en dit in die herinnering lewendig te hou. Daarby formuleer Dooyeweerd self sulke grondmotiewe uit sy eie nadenkende vergelykende rekonstruksie van die beskawingsgeskiedenis: die vorm-materiegrondmotief van die Griekse denke, die natuur-genademotief van die Middeleeue, en die natuur-vryheidmotief van die moderne tyd. Wat opval in hierdie rekonstruksie van grondmotiewe is dat die Bybelse een van skepping, sondeval en verlossing klaarblyklik self geen intellektuele geskiedenis het nie. Maar, en dit is die punt, die sogenaamde Bybelse grondmotief van skepping, sondeval en verlossing is op sy minste 'n konstruksie, waarvan die historiese aard vergeet en verberg word deur dit in verband te bring met die bestaan en die waarheid van God wat die tyd sou transendeer. Die Bybelse grondmotief kan as grondmotief nie aanspraak maak op goddelike openbaring nie. Enige vorm waarin dit geformuleer word, plaas dit onvermydelik in 'n interpretasietradisie. Dooyeweerd is in hierdie opsig nie krities genoeg nie. Hoe hierdie motief oor ' $n$ bepaalde tyd en onder bepaalde omstandighede binne 'n sekere gemeenskap ontstaan het, en hoe mense binne hierdie spesifieke gemeen- 
Transendentale kritiek en negatiew'e dialektiek

skap en die betekenis van die formulering gesosialiseer is, word nie bedink nie. Die motief self word aan die refleksie van die teoretiese denke onttrek. Dan kan die aanspraak gemaak word, soos Louet Feisser te kenne gee, dat 'n denke wat op Christus die Verlosser gerig is, bevry kan word van allerlei verabsoluterings, oftewel skeeftrekkings in sy verstaan van die werklikheid.

Hierdie aanspraak is die hybris van die reformatoriese filosofie. Omdat die inhoud van die Christelike grondmotief aan die kritiese refleksie van die teoretiese denke onttrek is en onkrities (as religie) absoluut gestel word, word die historiese en geinterpreteerde aard daarvan nie herken nie. Dit annekseer oorywerig die vernuwende krag van die verlossing deur Christus as ' $n$ magiese middel om filosofie as onbestrede in die forum van die filosowe te bedryf, en val vir die verleiding om ander - die (ongelowige) teenstander - van hulle denkworstelinge as hulle denkfoute waarvan hulle nie bewus is nie, te oortuig. Dit hou die reformatoriese filosofie voor as ' $n$ vind van panaseë, omdat dit - in sy intellektuele oorspronge - beskik oor die steen van wysheid. (In alle billikheid moet hier bygevoeg word dat daar wel rekening gehou word met 'n blywende hindernis waarteen voortdurend gestry moet word: die sondige aard van die mens, wat die verkeerde rigting van hierdie vertrekpunt af kan inslaan.) Of daar enige waarheid in hierdie aanspraak op vrywaring van spannings sit, of dat dit ' $n$ imperatief vir die Christenfilosoof word om alle kontradiksies in die denke te vermy, is te betwyfel. Dooyeweerd se eie denke is nie gevrywaar van logisisme nie: om die logikale verbod op kontradiksie te verhef tot indikasie van die betekenis van 'n religieuse grondmotief, is om die rol en betekenis van die logikale verbod op kontradiksie te verabsoluteer. Die versweë argument hier is dat die Bybelse grondmotief in sigself geen spanning bevat nie, want wat God is en doen, verkeer nie in teenspraak met Homself nie. As dit die geval is, is God onvolmaak, en dit in sigself is 'n teenstrydigheid. Enige ander teenstrydigheid, op watter vlak ook al, is 'n simptoom van die anwesigheid van 'n (meesal onbewuste) dieperliggende teenstrydigheid. En teenstrydighede is iets wat vir die denke aanstootlik is, en wat die denke onrustig maak. Die enigste rus wat die denke kan vind, het Augustinus volgehou, is die rus in God - waar alle teenstrydighede geblus word. So sê Dooyeweerd Augustinus ook na (Dooyeweerd, 1953:96-97). Teenstrydighede, in die vorm van kontradiksies, anomalieë en paradokse, is die gevolg van verabsoluterings uit 'n samehang, en is daarom eintlik 'n ongewenste verrekening van die samehangende verskeidenheid. Dit mag dan waar wees as Dooyeweerd 
Johan Snyman

beweer dat "the Christian religion, by virtue of its fulness of meaning, does not admit of any absolutizing ..." (Dooyeweerd 1953:104). Niks in die Skepping kan sigself bo die ander en bo God verhef nie, maar dit sluit nog nie die ervaring en die belewenis van die paradoksale uit nie! Enige religie is vol sulke ongerymdhede (waarvoor die denke verstom), en die fisika, die ekonomie en die estetika is nie denkbaar sonder verskillende vorme van volgehoue en onoplosbare kontradiksie nie. Die belewenis van die onuitspreeklike in godsdiens (byvoorbeeld sondebesef en genade in die Christelike godsdiens), entropie (in fisika), behoefte en vervulling (in ekonomie) en die interpretasie wat uitgestel word (in die kuns) is verskillende wyses van hierdie belewenis van die volheid van die werklikheid, wat eerder getuienis is van 'n 'ooraanbod' van betekenis as 'n getuienis van 'n oormoedige, selfgenoegsame en daarom misleide/misleidende rede. Paradokse, anomalieë en kontradiksies kan ander betekenisse hê as net simptome van 'n oorskatte selfgenoegsame redelikheid.

\section{Adorno as skyn(ver)werper}

Maar so maklik is dit egter ook nie om teenstrydighede te rehabiliteer nie. Daar is ' $n$ punt waarop kontradiksies skadelik word. Hiervan wil Adorno se negatiewe dialektiek ons oortuig. Hy noem hierdie negatiewe dialektiek by geleentheid 'n "ontologie van die valse toestand" (Adorno, 1967:20). Dit is die sosiale werklikheid tot die begrip gebring van sy eie dodelike teenstrydigheid van tegniese vooruitgang aan die een kant en die likwidering van die individu aan die ander kant. Terwyl die oppervlakte van die sosiale werklikheid lyk asof daar meer welvaart en groter differensiëring vir behoeftebevrediging is, is daar in werklikheid groter onderdrukking en ontkenning van die menslikheid van die mens onder die oppervlakte aan die gang. Of soos Marcuse (1964) dit in die openingsin van sy One-Dimensional Man dit stel: die kragte wat die mensdom kan uitwis, dien terselfdertyd as voortdurende regverdiging vir die belange om hulle te behou. Diep onder die oppervlak is die onopgeloste spanning van 'n veralgemeende belang en individuele belange. Die samelewing is eenvoudig nie die beliggaming van 'n egte algemene belang nie. "Die geheel is die onware" (Adorno, 1978:57). En wat is waar? Slegs dit wat nie in die beheerde, geadministreerde en gestuurde samelewing inpas nie, omdat dit iets allerindividueels - en daarom iets outentieks - verteenwoordig wat aan die gelykmakende en standaardiserende opset van die moderne funksionele samelewing ontsnap het. Wat die totale funksionele samelewing weerstaan, is afwykend, en moet ter wille van die geheel uitgewis word. In

Koers 60(2) 1995:213-236 
Transendentale kritiek en negatiewe dialektiek

hierdie opset is Auschwitz en die kultuurindustrie kante van dieselfde munt.

"Auschwitz is die uiterste sosiale feit" (Adorno, 1972b:277). Wat met Auschwitz in die geding is, kan nie afgemaak word as 'n "tussenspel" van die geskiedenis of as 'n "bedryfsongeluk in die segetog van die beskawing" nie (Adorno, 1978:65, 314). Auschwitz is 'n soort teken en sleutelervaring waarin die onderliggende dryfveer van die Westerse beskawing homself in sy uiterste vorm wys, naamlik die afskaffing - die uitwissing - van die individu. In Auschwitz het die maatskaplike druk "volgens wêreldhistoriese maat" gemeet, "gekulmineer". En Auschwitz bly in 'n sekere sin "voortbestaan solank as wat die voorwaardes wat daardie terugval [in barbarisme] opgelewer het, wesentlik voortduur" (Adorno, 1970:85). Die huidige tegnologies vooruitgegaande en geadministreerde soort samelewing waarin ons ons tans bevind, kan met 'n handomkeer nog 'n Auschwitz oplewer. Ten spyte van al die voonuitgang om siektes te bestry en om die lewe gemakliker te maak, en ten spyte van al die beheermaatreëls om 'n samelewing se funksionering te laat vlot, is die onheil van onverskilligheid teenoor menselewens net onder die oppervlak.

As uiterste sosiale feit laat Auschwitz hom nie verstaan nie. Geen voldoende redelike grond kan daarvoor aangevoer word nie, want die rede verstom in die angesig van soveel planmatig uitgevoerde onmenslikheid en totaal verstomde lyding. Die folteraar kan hierin ook nie tot verantwoording geroep word nie, want hy verdwyn agter die sisteem as dié se agent, en dus in ' $n$ sekere sin as die slagoffer daarvan. Lewe na Auschwitz kan nie normaal wees nie. Daarvoor is die logika van die geskiedenis net te destruktief: as die vermoordes gewreek word, word die katastrofe voortgesit; en word genade aan die moordenaars bewys, word daarmee eweneens bewys hoe maklik dit is om sulke misdade te pleeg.

Hierdie negatiewe geskiedenisfilosofie is die dieptepunt van 'n siening oor die "dialektiek van die Verligting" - 'n pessimisme wat die intellektuele voorvader van Dooyeweerd, naamlik Groen van Prinsterer, tot op sekere hoogte met Adorno kon deel. Die opmars van die rede is te wantrou. Vir Groen van Prinsterer het dit uitgeloop op "ongeloof en revolutie" (Groen van Prinsterer, 1847). Vir Adorno loop dit uit op 'n totaliteit "wat homself onder die druk van partikuliere rasionaliteit versterk" (Adorno, 1967:32), en wat kenbaar word in lyding. "Geen universele geskiedenis lei van die wilde mens tot humaniteit nie, maar wel een van die klipslinger na 
Johan Snyman

die megabom. Dit eindig in die totale bedreiging van die georganiseerde mense deur die georganiseerde mensheid" (Adorno, 1967:312).

Op 'n minder dramatiese, maar net so bedreigende skaal is die kultuurindustrie - die massavoorsiening van vermaak in die tegnologies vooruitstrewende samelewing met sy surplus aan vrye tyd. Kultuurindustrie is die nuwe opium. Deur die aanbieding van gestereotipeerde identifikasiemodelle ('sterre') word individualiteit in die samelewing afgeskaaf en afgeskaf. Die gesiglose werker ervaar vervulling en ontvang erkenning in die mate waarmee hy/sy op die beeld van die suksesvolle 'ster' begin lyk. Die geadministreerde mens word in sy/haar behoeftes beplan en gekontroleer. Die frustrasies van die alledaagse werklikheid word ontvlug in die skynoplossing van skynkonflikte in die seepopera - en die werklikheid van die alledaagse bly onveranderd (en seepglad). Die onmenslikheid van aanpassing by hierdie beheerde werklikheid word verdoesel deur die skyn van verhoogde verbruik van luukse goedere.

Adomo se afkeer van die afgelope geskiedenis en die eietydse samelewing is onaangename prikke tot morele oordele. Filosofie is slegs moontlik as die slegte gewete van die bestaande. Een so 'n onophoudelike kwelgedagte is die kompromislose afwysing van die negatiewe resultaat van vooruitgang. Op geen wyse mag hierdie negatiewe totaliteit - of soos Adorno dit noem: die totale verblindingsamehang - geregverdig word nie. $\mathrm{Om} \sin$ in die bestaande wêreld te vind, sou onregverdig wees teenoor diegene wat magteloos gely het, en sou 'n goedkoop versoening met 'n werklikheid wees wat voortgaan om lyding op 'n onbegryplike wyse voort te sit. Daarom: "Nie die goeie nie, maar die slegte is die voorwerp van teorie. [Teorie se] element is die vryheid, sy tema die onderdrukking" (Adorno, 1969:258). 'n Tweede voortdurende kwelgedagte is die "nuwe kategoriese imperatief" wat "Hitler op mense afgedwing het: om hulle denke en handeling so in te rig dat Auschwitz homself nie herhaal nie" (Adorno, 1967:356). 'n Derde element van 'n slegte gewete is 'n solidariteitsmotief. Die nuwe morele gebod laat homself liggaamlik voel as die "prakties geworde afsku voor die ondraaglike fisiese pyn" wat mense aangedoen is en aangedoen word. Lyding moet tot uitdrukking gebring word. "Die voortdurende lyding het soveel reg op uitdrukking as wat die gemartelde het om te brul" (Adorno, 1967:353). Lyding wat onopgemerk verbygaan, wek geen reaksie nie, en almal dink alles is nog wel. Terwyl lyding verstom en gesmoor word, word menslikheid, en ook medemenslikheid, vernietig. Solank as daar "die kleinste spoor van sinlose lyding" is

Koers 60(2) 1995:213-236 
in die wêreld, word die vooruitgangsidee geloënstraf omdat die potensiaal van onderdrukking steeds in die wêreld aanwesig bly. Die plek van geluk in die wêreld is in der waarheid vandag nog onbeset en onvervuld - die wêreld is ons woning nie, was Totius se versugting. Volgens Adorno is hierdie geluk die inhoud van die "materialistiese verlange", "die opstanding van die liggaam", die "liggaamlike drang" wat gestil is, pyn wat opgehef is (Adorno, 1967:205).

\section{Die armoede van die negatiewe dialektiek}

'n Mens kan verwag dat waar so 'n kompromislose samelewingskritiek uitgespreek word, daar in terme van iets wenslikers, iets menslikers, geoordeel word. Het Horkheimer dan nie in sy programgeskrif van 1937 verklaar dat die studie van die samelewing gelei word deur 'n idee van 'n regverdige samelewing nie? Wat presies is hierdie idee? Vir Adorno geld in ieder geval in die lig van sy eie gereflekteerde ervaring as Jood en as balling: die utopie van sommiges is die hel van ander. Daarom geen bloudrukke vir die verwerkliking van 'n alternatiewe samelewing nie bloudrukke bring gou dié soort magsverhoudings mee waarteen gewaak behoort te word. Wat die utopie - die idee van 'n regverdige samelewing betref, geld ' $n$ Ou-Testamentiese beeldverbod. Die alternatief bly, soos by Kant, hoogstens 'n kategoriese imperatief, 'n verpligting, 'n regulatiewe idee: iets wat breë riglyne gee, maar geen politieke program nie. Daarom dat Adorno verwag dat die redding van die nie-identiese (dit wat nie in die geadministreerde en beheerde samelewing geassimileer kan word nie) nie in die politiek nie, maar buite-filosofies in die estetika en die kuns lewend gehou word. Presies dit is die betekenis van byvoorbeeld Arnold Schönberg se dissonante musiek: dit deurbreek met die lelike klank die valsheid van 'n orde wat op die oppervlakte harmonieus is, maar diep onder gefundeer is op onderdrukking en pyn in allerlei gedaantes. Alban Berg se Wozzeck is die eerste opera van die "reële humanisme". Dit sê: Ecce homo - kyk, die mens: 'n slagoffer van onmenslike oorheersing. Oor die algemeen geld dan vir Adorno dat kuns

$$
\begin{aligned}
& \text {... dit wat as die lelike vermy word, tot sy eie saak maak. Maar dan nie } \\
& \text { langer om dit te integreer of om dit te versag of deur humor (wat afstootliker } \\
& \text { as alle afstootlikheid is) met sy eie bestaan te versoen nie. In die lelike moet } \\
& \text { die wêreld aan die kaak gestel word - die wêreld wat die lelike na sy beeld } \\
& \text { skep en reproduseer (Adorno, 1972a:78-9). }
\end{aligned}
$$

Kuns is vir Adorno die "trustee van hoop": dit sê dat die beter wêreld nog nie is nie. Die utopie is onvervul, en daarom moet daar nog gehoop word. 
Johan Snyman

Die uiterste aan kwaad is bereik, maar nog lank nie dié van die goeie nie. Alfred Schmidt praat in hierdie verband van 'n onuitgemaakte saak by Adorno: "Die saak van die mensheid is wat Adorno betref, nog nie gewonne nie maar ook nog nie finaal verlore nie" (Schmidt, 1971:75).

Dit is op hierdie punt dat Adorno meer vrae as antwoorde begin oproep. Hier moet 'n mens saam met die kritici van Adorno begin praat van die armoede van die negatiewe dialektiek. Adorno se kritiese samelewingsteorie word oorweldig en verlam deur die kwaad. Die filosofie laat na om die werklikheid te verander. Dit interpreteer net, en soek uitkoms in die estetika en die kuns. Die interpretasie bring die denke voor 'n afgrond te staan. Dit wat nog werklikheid moet word teenoor die geheel van die onware, is iets waars wat geheel anders is as wat vir die denke voorstelbaar is. Ter wille van die behoud van die moontlikheid van die gans Andere (die regverdige samelewing) moet die denke sy reflektering na aanleiding van kunswerke vervat. Die geleentheid wat denke gehad het om homself te verwerklik, is onherroeplik verby. Filosofie bestaan nog slegs as teorie omdat dit nie verwerklik is nie (en nie die vooruitsig van sy verwerkliking het nie). Negatiewe dialektiek is dan die treurige paradoks van ' $n$ wil tot ' $n$ alternatief (wat nie kan nie) en wat tog bly leef het by enkele individue, of waarop nog 'n appél gemaak kan word by mense ondanks die verdorwe strukture waarin hulle leef. Gelyktydig egter is negatiewe dialektiek die poging tot 'n bestekopname van 'n revolusie wat toe dit kon plaasvind, nie wou plaasvind nie. Filosofie moet abdikeer. "Is die tyd van die interpretasie van die wêreld verby en gaan dit daarom om dit te verander, dan neem filosofie afskeid ... Dit is nie die tyd vir Eerste Filosofie nie, maar vir 'n laaste", sê Adorno heel dramaties in die voorwoord van een van sy werke (Adorno, 1975:47). Hierop antwoord HansJürgen Krahl sinies: "Hierdie laaste filosofie van Adorno het nie van sy afskeid afskeid kon of wou neem nie" (Krahl, 1971:288). Adorno se filosofie loop uit op 'n "profane negatiewe teologie" wat as kritiese ironiserende filosofie "die soort vemietiging is wat in werklikheid niks vernietig nie" (Marquard, 1975:189). Op die duur negeer dit niks, en wen dit geen veld nie.

\section{Tussen oormoed en armoede: waarnatoe?}

Is die moontlikhede van ' $n$ kritiese samelewingsfilosofie uitgeput met die probleme aan die ontwerpe van 'n Dooyeweerd en 'n Adorno? En is 'n Christelike samelewingskritiek daarom onmoontlik en onwenslik? Ek dink 
nie so nie. Dit is moontlik en wenslik, maar slegs in soverre as wat die aansprake van so 'n filosofie so oop, so wyd en so diep as wat maar enigsins kan, beproef word. Die ontgogeling met die rede kan iets vrugbaars wees - in plaas daarvan om af te sien van enige vorm van redelikheid en irrasionalisme te omhels, kan alternatiewe vorme van redelikheid verken word, soos sogenaamde postmoderne kritici van die moderniteitsprojek voorstel. Baie sketsmatig gesê, wil ek beweer dat Dooyeweerd se radikalisering van die Reformasie in ooreenstemming met hierdie voorstel van postmoderne kritici is. Daar is meer as een manier waarop 'n mens 'n Christen kan wees, maar dit het die implikasie dat Dooyeweerd se teorie van grondmotiewe laat vaar word. Dooyeweerd se eie uitwerking daarvan is self te veel gebonde aan die gees van moderniteit. Dit word 'n doktrine, 'n wysgerige sisteem met 'n sentrum, 'n allesbeheersende totaliteitsblik: die 'leer' van die wetskringe, die 'leer' van die individualiteitstrukture. In die plek daarvan wil ek voorstel dat die teorie van die grondmotiewe van sy sterk gedragswetenskaplike konnotasies gerehabiliteer word tot iets meer esteties (dit is die toegewing wat ek aan postmoderne vorme van alternatiewe redelikheid wil maak). Dit impliseer dat ' $n$ mens eerder sal uitgaan van die gegewenheid van 'n breë Christelike tradisie wat nie onder enkele noemers tuisgebring kan word nie, maar waaruit geput en waarmee kreatief omgegaan kan word. Die moontlikheid van 'n Christelike filosofie is geleë in die kritiese gespreksgemeenskap wat die Christelike tradisie in der waarheid is: interpretasies van God onder 'n veelheid van konkrete historiese omstandighede - terug te vind in die oorgelewerde dokumentasies daarvan (die Bybel) - wat met mekaar meeding om die onuitspreeklike in die veelheid van beperkinge van die menslike taal tot uitdrukking te bring. Hierdie gesprek is ten spyte van die talle pogings tot institusionalisering van interpretasies (in interpretasiekánons soos belydenisskrifte of skole) steeds oop, vir die belangrike rede dat ons vorige interpretasies altyd weer kan verken ter wille van moontlikhede wat nie genoeg benut is nie.

Ons interpretasies van (interpretasies van) God het 'n uitwerking op onsself, ander mense en die wêreld. Dit bly waar van die argument waarmee Calvyn se Institusie begin en wat Dooyeweerd onderstreep (Dooyeweerd, 1953:196): ons verstaan van die wêreld is afhanklik van ons verstaan van onsself, en ons selfverstaan is afhanklik van hoe ons God verstaan. Die implikasie hiervan is egter dat ons deur ons wêreldverstaan krities bewus moet word van ons verstaan van God. Dit is op hierdie punt dat Adorno se filosofiese refleksie oor die betekenis van Auschwitz 
relevant is. Ons verstaan van God en ons verstaan van die voorkoms van katastrofes soos Auschwitz (en die herhalings van Auschwitz in Biafra, Rwanda, Oos-Timor, Irak en Bosnië-Herzegowina in die heel jongste verlede) bly mekaar uitdaag. Dit is wat tot filosofie aanleiding gee - soos Nietzsche Zarathustra laat sing: Weh spricht: Vergeh! Die toetssteen van 'n verstaan van God is reaksie op lyding wat ander aangedoen word. As daar mense is wat God só verstaan dat hulle onaangeraak deur die lyding van ander kan bly leef, het hierdie ander goeie rede om hierdie verstaan van God in twyfel te trek, selfs te verag. Dan is hierdie veragtelike verstaan van God inderdaad onmenslik. Of is dit 'maar' menslik om (so) onmenslik te wees? Hoe los ons hierdie paradoks op?

Vir die huidige kies ek die kortpad van die kuns. J. van Melle gee ons 'n aanduiding in die slot van sy verhaal, "Oom Diederik leer om te huil", van 1938. Oom Diederik, die hoofkarakter van hierdie verhaal, is sterwend. As hy sy bewussyn verloor, of as die koors hom pak, kry hy drome. Hy gaan op reis. Op hierdie reis moet hy deur hekke gaan. Aanvanklik is die hekke - soos alle plaashekke - onbewaak. Maar mettertyd verskyn wagte by die hekke, en dit verg al hoe meer verduideliking om by die hekke deurgelaat te word. Uiteindelik is daar 'n hek waar oom Diederik nie kan deur nie, en hy moet omdraai. Wanneer hy weer by sy bewussyn is, kom die predikant hom besoek. Die res van die verhaal verloop soos volg:

"Dominee kan 'n stukkie vir my lees as Dominee wil," sê hy na 'n tyd.

Sy vrou kry die Bybel en die predikant dink wat hy sal soek. Die woorde van oom Diederik het hom egter laat sleg voel en hy sit daaroor en dink terwyl hy soek. Hy weet waarlik nie wat hy moet lees nie.

"Het oom Diek voorkeur vir die een of ander gedeelte?" vra hy.

"Nee, Dominee kan maar enigiets lees."

"Dan sal ek sommer hier lees waar dit oopgeval het."

Hy voel 'n bietjie skaam dat hy nie 'n toepaslike gedeelte in sy gedagtes kan kry nie en met weinig besieling begin hy lees. Hy lees 'n gedeelte van Mattheus 19. Oom Diederik neem elke woord op al lyk dit of hy skaars hoor.

Hoe verder die predikant lees hoe meer meen hy dat hy nou iets lees wat weinig troos of bemoediging in hierdie oomblik kan gee; dat dit jammer is dat hy nie iets meer toepasliks gesoek het nie. Tot hy kom by die een-enveertigste vers: "En als Hij nabij kwam en de stad zag, weende Hij over haar."

Toe hy daar kom, sê oom Diederik: "Dankie, Dominee, dis genoeg. Ek weet nou wat ek wou geweet het." 
Transendentale kritiek en negatiewe dialektiek

Verwonderd wag hulle of hy meer sal sê, maar hy bly swyg.

"Wat is dit, oom Diek?" vra die predikant. "Wat was dit wat oom Diek wou geweet het?"

Maar oom Diederik het geen lus om van die droom te vertel nie en hy sê: "Die Woord is darem wonderlik, Dominee. Dit gee jou antwoord op al jou vrae."

"Ja, oom Diek?" vra die predikant.

Maar oom Diederik sê niks meer nie. Roerloos sit hy daar soos 'n beeld van was. Hy sit daar so stil asof alles in hom onbeweeglik is, asof al sy gedagtes slaap, soos 'n grou water in skemering; soos 'n sandplaat by nag. Hulle sit hom en bekyk. 'n Ou man, 'n mens by die poort van die dood; een wat die hek weldra sal deurgaan.

'n Buitengewone stemming is in die kamer. Sonder beweging sit die vier mense daar en niemand praat ' $n$ woord nie. Die drie sit soos drie wat kyk hoe een van hulle vir goed weggaan, soos drie mense 'n wa nakyk wat wegry. Daar gaan hy heen en neem alles saam wat hy het, sy geloof, sy berou, sy werke: goeie en kwaaie. Watter soort vrag is daar op sy wa? So sit hulle daar en dink.

Die son sak en goudagtig skyn sy strale deur die een venster. Die stil mense maak dit alles nog plegtiger.

Eindelik staan die predikant op en oom Diederik sit weer alleen met sy gedagtes. Hy sien dat sy kar ingespan staan, opgepak en klaar om te ry. Alles wat hy nodig het is op, net die trane, die regte trane, ontbreek. Hy sien voonuit reeds al die hekke wat hy sal moet deurgaan en hy weet nou dat dit nie moeilik sal wees nie, dat hulle hom oral sal deurlaat; net die laaste hek sal hy nie kan deurgaan nie; daar gaan alleen die mense deur wat huil; trane huil wat nooit ophou vloei nie; waar jy is, hier op aarde of van die aarde weg, aanhou vloei solank die mensdom in nood en sonde leef. Mag hy dan nie daardie trane hê nie?

Groot droefheid vervul hom, 'n bitter droefheid dat hy oud geword het, sewentig jaar geleef het sonder daardie trane te huil, regtig daardie trane te huil en hy bid om daardie droefheid wat sal aanhou, aanhou solank die son op 'n onveranderde aarde skyn (Van Melle, 1938:154-157).

\section{Bibliografie}

ADORNO, T.W. 1967. Negative Dialektik. Frankfurt a.M. : Suhrkamp.

ADORNO, T.W. \& HORKHEIMER, M. 1969. Dialektik der Aufklärung. Frankfurt a. M. : Fischer.

ADORNO, T.W. 1970. Stichworte. Kritische Modelle 2. Frankfurt a.M. : Suhrkamp.

ADORNO, T.W. 1972a. Ästhetische Theorie. (Gesammelte Schriften, Bd. 7.) Frankfurt a.M. : Suhrkamp. 
Johan Snyman

ADORNO, T.W. 1972b. Soziologische Schriften 1. (Gesammelte Schriften, Bd. 8.) Frankfurt a.M. : Suhrkamp.

ADORNO, T.W. 1975. Metakritik der Erkenntnistheorie. Drei Studien zu Hegel. (Gesammelte Schriften, Bd. 5.) Frankfurt a.M. : Suhrkamp.

ADORNO, T.W. 1978. Minima Moralia. Frankfurt a.M. : Suhrkamp.

BLUMENBERG, H. 1974. Säkularisierung und Selbstbehauptung. Frankfurt a.M. : Suhrkamp.

DOOYEWEERD, H. 1953. A New Critique of Theoretical Thought. (Volume 1.) Amsterdam : Paris.

DOOYEWEERD, H. 1979[1959]. Roots of Western Culture. Pagan, Secular and Christian Options. Toronto : Wedge Publishing Foundation.

GROEN VAN PRINSTERER, G. 1868[1847]. Ongeloof en revolutie. Franeker : Wever.

HABERMAS, J. 1981. Theorie des kommunikativen Handelns. Frankfurt a.M. : Suhrkamp.

HABERMAS, J. 1985. Der philosophische Diskurs der Moderne. Frankfurt a.M. : Suhrkamp.

HORKHEIMER, M. 1968 [1937]. Traditionelle und kritische Theorie. Frankfurt a.M. : Fischer.

KRAHL, H.-J. 1971. Konstitution und Klassenkampf. Zur historischen Dialektik von bürgerlicher Emanzipation und proletarischer Revolution. Frankfurt a.M. : Verlag Neue Kritik.

LOUET FEISSER, J.J. 1961. De bijdrage van de Wijsbegeerte der Wetsidee tot de vernieuwing van het philosophisch inzicht. (In Van Dijk, W.K. e.a. Perspectief. Feestbundel van de Jongeren bij het vijfentwintig jarig bestaan van de Vereniging voor Calvinistische Wijsbegeerte. Kampen : Kok. p. 18-35.)

MacINTYRE, A. 1981. After Virtue. A Study in Moral Theory. London: Duckworth.

MARQUARD, O. 1975. Uber positive und negative Philosophien, Analytiken und Dialektiken, Beamte und Ironiker und einige damit zusammenhängende Gegenstände. (In Weinrich, Harald, red. Positionen der Negativität. München : Fink. p. 177-199.)

MARCUSE, H. 1964. One-Dimensional Man. London : Routledge \& Kegan Paul.

SCHMIDT, A. 1971. Adorno - ein Philosoph des realen Humanismus. (In Schweppenhäuser, H., red. Theodor W. Adorno zum Gedächtnis. Eine Sammlung. Frankfurt a.M. : Suhrkamp. p. 52-75.)

TAYLOR, C. 1989. Sources of the Self. The Making of the Modern Identity. Cambridge (Ma.) : Harvard University Press.

VAN DIJK, W.K. e.a. 1961. Perspectief. Feestbundel van de Jongeren bij het vijfentwintigjarig bestaan van de Vereniging voor Calvinistische Wijsbegeerte. Kampen : Kok. 
Transendentale kritick en negatiewe dialektiek

VAN MELLE, J. 1938. Vergesigte. Pretoria : Van Schaik.

VAN RIESSEN, H. 1957. Maatschappij der toekomst. Kampen : Kok.

VERSFELD, M. 1986. Hoekom filosowe nog steeds teen die wind spoeg. (In

Du Toit, A., red. In gesprek. Opstelle vir Johan Degenaar. Kaapstad :

Die Suid-Afrikaan. p. 2-5.) 